\title{
Implementation of Differentiated Instruction in Middle School Classrooms: A Qualitative Study
}

\author{
LaToya Benjamin ${ }^{1} \&$ Sunddip Panesar-Aguilar2,* \\ ${ }^{1}$ School of Education, Walden University, Minneapolis, Minnesota, United States \\ ${ }^{2}$ College of Health Sciences, University of St. Augustine, Florida, United States \\ *Correspondence: College of Health Sciences, University of St. Augustine, St. Augustine, FL, United States. Tel: 1- \\ 904-770-3676. E-mail: saguilar@usa.edu
}

Received: January 25, 2020

Accepted: February 8, $2020 \quad$ Online Published: February 19, 2020

doi:10.5430/wje.v10n1p81

URL: https://doi.org/10.5430/wje.v10n1p81

\begin{abstract}
Despite research on the benefits of implementing Differentiated Instruction (DI) practices within an inclusive classroom, many teachers do not utilize the practice regularly. An instrumental case study that included teachers from 1 middle school in a rural school district in a southeastern state was used as the qualitative research design in this study. The purpose was to explore rural middle school teachers' experiences and challenges with incorporating the components of DI to support special education students in inclusion classrooms. Tomlinson's model of DI as it relates to teachers providing responsive instruction to meet the needs of each of their students regardless of their ability was used as the conceptual framework. A purposeful sample of 10 middle school teachers Grades 6-8 from various content areas in the school participated in interviews, observations, and submitted documents for review. Data were coded and thematic relationships and patterns related to the DI framework emerged. Themes included concerns regarding teachers' lack of knowledge and professional development for fidelity of implementation of DI with special needs students, insufficient resources to support implementation of DI, and concerns with class size and accommodation of DI needs of all students within an inclusion-based classroom. Based on the results, the research may contribute to positive social change by helping middle school teachers use the components of DI in their inclusion-based classes and by providing instructional support to enhance learning and increase academic success for special education students.
\end{abstract}

Keywords: special education, differentiated instruction, inclusive classroom, inclusion

\section{Introduction}

In the United States (U.S.), schools continue to experience rapid and regular changes in their curricula (National Center for Education Statistics [NCES], 2017). According to Wiles and Bondi (2015), the changes within the curriculum require teachers to possess the skill set and knowledge to implement instruction with fidelity and to ensure that all students receive a quality education. This may improve teacher efficacy which may impact their delivery and purpose of the material they are using for effective implementation (Avery, 2017). Whether curriculum is delivered consistently, effectively, and with the efficacy necessary for supporting student achievement is contingent on the centralization of teachers, or the teacher's ability to make decisions about the content being delivered, the process by which the content is delivered, and the product by which student mastery is assessed (Lochner, Conrad, \& Graham, 2015).

The introduction of new laws, mandates, and standardized assessments create an ever-changing pedagogical environment in education (Avery, 2017). A new initiative, Every Student Succeeds Act (Every Student Succeeds Act [ESSA], 2015) was signed into legislation to support academic success. ESSA replaced the highly controversial No Child Left Behind (NCLB) Act (2002), a federal mandate which required all states to administer standardized assessments to students in grades three through 10 to determine grade-level proficiency. Under NCLB, all students were required to achieve grade-level proficiency by the 2013-14 school year; however, the standardization of education, providing a one size fits all education for students, did not offer students within population subgroups, such as English for Speakers of Other Languages (ESOL) and students with learning disabilities, the opportunity to be successful. ESSA embodies the nation's commitment that every child in grades $\mathrm{K}-12$ is afforded an equal and quality 
education despite their gender, ethnicity, or disability (Darrow, 2016). According to Darrow (2016), students' progress and mastery were measured only by way of standardized testing under NCLB. There is more accountability on the district and state levels rather than from the federal government regarding testing under ESSA. Like NCLB, ESSA follows the accommodations and guidelines put in place by the Individual with Disabilities Act (Individual with Disabilities Act [IDEA], 2004) passed in 2004 (Darrow, 2016).

The implementation of this act mandated that students with special needs be placed in the least restricted environment (LRE) for learning (Bichehouse \& Faieta, 2016). According to IDEA, the LRE for many students is a general education classroom setting, where students with special needs are included with nondisabled students within the same classroom environment. This is also known as inclusion. According to Forrester (2016), inclusion is an environment that allows students with disabilities to be placed in an educational setting with their nondisabled counterparts. However, the problem with this model of inclusion is that regular classroom teachers lack the training and knowledge to teach effectively in an inclusion setting. An increase in teacher responsibility, inadequate teacher preparation, a lack of pedagogical skills, and teacher attitudes and dispositions have an impact on the success of the implementation of inclusive practices within a classroom setting (Florian \& Beaton, 2017).

The National Center for Educational Statistics reported $95 \%$ of students with disabilities (as defined by the IDEA) are placed in an inclusive classroom, and approximately $40 \%$ are placed in general education classrooms (U.S. Department of Education, n.d.). Steinmeyer (2011) stated an inclusion setting provides best practices for students with disabilities to become successful. During the 2015-2016 school year, the South Carolina (SC) Department of Education Office of Special Education reported that approximately $55 \%$ of students with individualized educational plans (IEPs) included in general education classrooms at the South Carolina school district were not achieving at high levels academically (SC Department of Education, 2015). Prince (2016) suggested that one effective way educators could provide support to SPED students in an inclusion class is through the implementation of differentiated instruction (DI).

DI has been the bridge in meeting the diverse needs of students to increase student learning, as well as influencing teacher effectiveness as measured by student achievement (Prince, 2016). According to Tomlinson and Imbeau (2010), teachers should use a plethora of instructional strategies to address the influx of children from various backgrounds and cultures. DI is one approach toward accomplishing the task of educating all students. However, the problem lies in teacher preparedness and the understanding of DI strategies regarding content, process and product of learning, as well as the effects of DI on student achievement. The challenges of implementing DI was the foundation of this study. Unless the affective domain of DI is addressed in inclusive classrooms, there may be a gap in teachers' instructional practices that could hinder the achievement of students with special needs (Dixon, Yssel, McConnell, \& Hardin, 2014).

There is a plethora of research on DI. The research reveals an achievement gap between general education and special needs students which can be reduced with effectively implementing DI within an inclusive classroom (Tomlinson \& Imbeau, 2009). Avery (2017) cited that DI is one of the most common instructional strategies used to bridge the achievement gap and meet the individual learning needs of each student based on where they are academically. Nicolae (2014) conveyed that the implementation of DI is meant to bridge the gap between teaching and learning, allowing all students to learn. Dixion et al. (2014) suggest that DI is a philosophy that focuses on what each student needs to be successful academically. In addition, DI forces teachers to think more critically about pedagogy (Dixion et al., 2014). Royster, Reglin, and Losike-Sedimo (2014) stated that DI is an appropriate practice to increase learning outcomes for special education students because it allows teachers to respond to diverse learning, creating a positive influence on students.

With the increase in SPED students in general education classrooms, it is crucial that general education teachers are equipped with tools and strategies to provide effective instruction in an inclusive classroom (Dixon et al., 2014). Therefore, it is required that general education teachers become proactive, seeking training, to serve students with learning disabilities (Royster et al., 2014). It was reported that teachers who were more knowledgeable and received training were more accepting of SPED students in a general education classroom (Prince, 2016).

Research suggests that DI improves the possibility of academic success for diverse students (Avery, 2017; Florian \& Beaton, 2017). According to current literature, the use of DI creates independent, responsible, and confident learners. Moreover, it moves students toward academic achievement by meeting their individual needs (Avery, 2017).

\subsection{Purpose}

The purpose of this qualitative instrumental case study was to explore rural middle school teachers' experiences with incorporating the components of DI with special education students in an inclusion classroom. To address the problem, an instrumental case study was used to explore the knowledge and implementation of DI by middle school teachers and 
its effect on student achievement. Data was collected using interviews, observations, and document analyses.

\subsection{Research Questions}

The research questions for this qualitative instrumental case study were:

RQ1: What type of training, if any, have rural middle school teachers had with teaching the components (content, process and product) of DI within their inclusive classrooms to support SPED students?

RQ2: How do rural middle school teachers use the components of DI to support SPED students within an inclusion class?

RQ3: How do the components of DI used by the teachers at the school of study align with best practices in DI to support SPED students within an inclusion class?

RQ4: What challenges do middle school teachers at the school of study face with incorporating the components of DI to support SPED students in an inclusion class?

\section{Method}

The school district of study is in the southeastern region of South Carolina and enrolls approximately 10,000 students from Pre-K to 12th grade. However, the focus for this study consisted of one rural middle school within the district of study, which serves approximately 550 students in grades 6-8 with a diverse population where $69 \%$ of the students are eligible for free and reduced lunch. According to the Department of Education (2016), the enrollment of students was: $33 \%$ White, 53\% Black, 12\% Hispanic/Latino, 1\% Asian, and 2\% Multiracial. During that year, 98 students or 18\% were classified as SPED students, and 35\% of the students were placed in an inclusion-based classroom (South Carolina Depart of Education, 2016). The SPED students in the school of study received instruction through a co-taught inclusion model or push in by a SPED teacher. However, the number of inclusion students varied from class to class.

There were 24 middle school teachers $(n=24)$ at the study site. Inviting all 24 of the teachers for the study increased the possible number of participants and allowed for a generalization of the data collected. A purposeful sampling was used and 10 willing participants were invited to participate in the study: two participants who taught English and language arts (ELA), two participants who taught math, two participants who taught social studies, two participants who taught science, one participant who taught English for Speakers of Other Languages (ESOL) students, and one participant who taught SPED.

\section{Results}

\subsection{Interviews}

During the interview process, the teachers acknowledged the importance of using DI as an instructional strategy to support all students and how it could enhance the academic achievement for SPED students. However, they also expressed their challenges when incorporating the elements of DI to support SPED students in an inclusion-based classroom. All the teachers were aware of the benefits of using DI within their inclusion-based classroom, but they lacked the time it took to plan and prepare adequately for it. Recurring themes were prevalent during the interviews: (1) Knowledge of DI, (2) Training/Professional Development (3) Challenges of DI, (4) Resources/Support, (4) Implementing DI, and (5) Using Technology in DI. Each interview ranged from 45-60 minutes. Table 1 illustrates the background of the participants in the study. 
Table 1. Teacher Demographic Information, Experience, Class Size, Number of SPED students, and Course (s) Taught

\begin{tabular}{|c|c|c|c|c|c|}
\hline Participant & Gender & Experience & $\begin{array}{l}\text { Class } \\
\text { Size }\end{array}$ & $\begin{array}{c}\text { Number of SPED } \\
\text { Students }\end{array}$ & Course(s) Taught \\
\hline A & $\mathrm{F}$ & 3 & 25 & 13 & $\begin{array}{l}7^{\text {th }} \text { Grade ELA and } 7^{\text {th }} \text { Grade } \\
\text { Social Studies }\end{array}$ \\
\hline B & $\mathrm{F}$ & 40 & 10 & 10 & ESOL Class \\
\hline $\mathrm{C}$ & $\mathrm{F}$ & 20 & 22 & 10 & $\begin{array}{l}7^{\text {th }} \text { Grade Pre-AP Math; } 7^{\text {th }} \\
\text { Grade AP Math }\end{array}$ \\
\hline $\mathrm{D}$ & $\mathrm{F}$ & 20 & 22 & 15 & $7^{\text {th }}$ Grade Science \\
\hline $\mathrm{E}$ & $\mathrm{F}$ & 8 & 23 & 10 & $6^{\text {th }}$ Grade Science \\
\hline $\mathrm{F}$ & M & 2 & 20 & 14 & $7^{\text {th }}$ Grade Social Studies \\
\hline G & M & 8 & 22 & 17 & $8^{\text {th }}$ Grade Social Studies \\
\hline $\mathrm{H}$ & $\mathrm{F}$ & 12 & 25 & 10 & $\begin{array}{l}7^{\text {th }} \text { Grade Pre-AP ELA; } 7^{\text {th }} \text { Grade } \\
\text { AP ELA (Gifted and Talented) }\end{array}$ \\
\hline I & $\mathrm{F}$ & 27 & 15 & 15 & $\begin{array}{l}7^{\text {th }} \text { Grade Special Education and } \\
\text { Inclusion Teacher }\end{array}$ \\
\hline $\mathrm{J}$ & $\mathrm{F}$ & 7 & 20 & 11 & $6^{\text {th }}$ Grade Math \\
\hline
\end{tabular}

The interview addressed the following questions and responses of each participant.

Knowledge about DI: "What is your background knowledge about DI?" All the participants had basic knowledge of DI. It was a consensus that the knowledge and understanding they have about DI came from their studies as an undergraduate or graduate student. During the interview process, they also acknowledged the importance of using DI to support all students. To gather more information, participants were asked to elaborate by asking, "How would you define DI?" Most of the teachers gave similar responses by acknowledging that all students learn on different levels and that DI can be used to benefit students, especially the SPED population. Teacher F stated, "It's meeting students where they are." Teacher H stated, "DI is providing students a different way of learning." Teacher J elaborated, "I think DI is using different learning styles to enhance student success." Teacher G expressed, "I really do not know a lot about DI other than what it has been told to me in various classes for alternative certification, but I know it's about meeting students where they are, which I struggle to do."

Furthermore, Teacher A expressed, "Really DI is meeting the students where they are but pushing them to the next level by offering different opportunities for them to show it." Finally, Teacher B stated, "DI is an instructional tool that uses different instructional strategies to meet individual student needs."

Training/Professional Development: "To your knowledge, how much training or professional development on using the components of DI to support SPED students is offered to middle school teachers?" Some of the teachers agreed that they have minimal to no training, and that there is a need for more training where DI is modeled for them. The responses varied on when they received any professional development or attended a workshop about DI and whether they found it beneficial.

Teacher $\mathrm{H}$ expressed that the best professional development she attended was a STEM workshop. She stated:

The school sent me to a STEM workshop. The basics of this workshop were using the four C's: communicate, collaborate, critical thinking, and creativity to differentiate instruction within classrooms. It was a chance for teachers in all content areas to share what instructional strategies and activities they were using to implement the $4 \mathrm{C}$ 's and what they found successful. The presenters provided us with examples of each component and modeled the use of the components. The teachers were given a chance to be the students as well. It was a great experience. However, I have not had any other professional development training on DI.

Teacher $\mathrm{H}$ felt that the workshop provided her with resources that she could use to enhance learning and increase student achievement amongst all students, stating, "It was refreshing to attend a workshop that was engaging and hands-on." Teacher $\mathrm{H}$ also stated that "Other than the STEAM training. I haven't had any other training or professional development in DI." In contrast, Teacher I said, "Since teaching middle school (she previously taught 
high school ELA), I have not been provided the opportunity to further my knowledge of DI. I do believe that DI is woven into other professional developments I have attended." Teacher D elaborated on the other professional developments she attended as it related to DI. She stated:

I participated in an ELA workshop on how to incorporate text-dependent analysis, TDA, and other literary components to strengthen students' reading skillsets. We learned about different strategies, such as summarizing, anticipation guides, and vocabulary building techniques that all students can benefit from using. However, it did not provide information on how to differentiate that.

Teacher A expressed that she has been offered various opportunities for professional development via departmental meetings. She stated, "I feel like more opportunities should have been presented. Although, we were given a snapshot on using DI, it was not modeled, and time was short." Teacher B, Teacher D, and Teacher G stated they received very little training in DI. Teacher G said, "We have been told by the administrative team to differentiate and show in our lesson plans how we were going to differentiate, but we were never shown what that looks like." Teacher C expressed, "There have not been any professional development opportunities that I am aware of that focus specifically on how to differentiate instruction for students with disabilities." In contrast, Teacher C, Teacher E, Teacher F, and Teacher J expressed that they have not been offered any form of training in DI.

Question 6 and Question 7: "If you were not offered any professional development, have you attempted to attend any professional development sessions geared toward DI? If so, what did you find useful? Explain?" Teacher D stated previously that he had little training, he said, "I had to read a book about DI. After reading the book, I had to apply the activities learned in order to meet the needs of my students. I found the information to be useful because it provided me with different strategies to add to my curriculum to create a meaningful learning environment, but it has not been modeled for me on what the implementation of these strategies would look like for my classes. It has to be ongoing, not just for a workshop or breakout session at the beginning of the year."

Teacher H previous stated that she did attend a professional development training. She stated, "I found the STEM workshop to be useful, especially the shared inquiry. It focused on critical thinking. Using the four C's ensures that the students are focused. The workshop showed how students could pull evidence to improve their writing." Teacher H's followed up this response by asking, "How can the four C's be applied for special education students?" Teacher $\mathrm{H}$ stated, "I'm sure it can be applied with all students, including SPED students. However, it will take a lot of planning and collaborating to come up with an activity that is tailored to meet their learning needs." Teacher A expressed that, "Although we have had some professional development during planning, it has been hard finding PD on my own." Teacher B said, "Yes, I have attended an ESLO professional development training. I found it very useful. This training provided me with resources and skills for general education teachers to use when working with ESLO students." Teacher's C, E, and F stated they have not attempted to find any professional development related to DI. Numerous times throughout the interviews, the teachers voiced their interest in obtaining some professional development on how to incorporate the elements of DI to support all their students and enhance the learning to support the SPED students within their inclusion-based classrooms. Teachers D, E, F, G, and H stated that they have not been provided with professional development of any kind in approximately four years due various circumstances.

Challenges of DI: "What challenges, if any, do you face with using the components of DI to support SPED students in your inclusion-based classes?" All the participants agreed that the use of DI could be beneficial toward student achievement. However, they also agreed that there were some barriers. Many agreed that the challenges they faced were the varied levels within a class, lack of planning time, and a lack of resources.

Teacher D stated a major barrier to be the number of ESOL students in his classroom and trying to determine the best method to reach each of them. He said,

My largest class has 25 students. In that class, I may have 5-10 students who are ESOL or classified as SPED with an IEP. I have a hard time finding ways to reach those students. Our ESOL teacher will push in on various days to assist, but it's not enough. I'm always unsure if what I do is working or even if they understand.

Teacher E also commented on the varied levels of learning. She said, "My classroom includes students with a wide range of learning disabilities/challenges. I have one class that includes students who have reading levels ranging from grade 2 to grade 6. It's difficult to differentiate while meeting everyone's needs with such a wide range of level abilities." Teacher J expressed, "My biggest challenge is creating lessons that are specific to each student's need." Teacher $\mathrm{H}$ stated his biggest challenge was foundational skills related to vocabulary. He stated,

I find it hard to teach any lesson when my students do not understand the vocabulary due to their level of learning. For example, I teach capitalism which is a free market. Then, I have to explain what a market is. This prevents me from 
really teaching to the standard when I spend so much time with vocabulary building. I still do not know the best way to reach my lower level learners while staying true to the content.

Teacher G stated, "My challenges are having varied learning levels within my class and not knowing if I'm actually meeting their needs." The participant was asked to elaborate, and he stated, "The administration team does not do a good job with communicating about PD and how to use DI within our classrooms. Issues with using DI are class size, lack of resources, lack of knowledge and no communication. They [district] give us a lot of "lip service" on things they have planned but there is no follow-through. I have basic knowledge of what DI is, but it has not been modeled. It's also difficult for me to differentiate any lesson when I have a large class with each student reading on different levels." Teacher B mentioned the lack of support. She stated, "As an ESOL teacher, the challenge I see is the lack of support for general education teachers." She further explained, "General education teachers are asked to provide the same work to all students and are not given support on how to do so."

Questions 9-12, instructional practice questions, focused on the participants' instructional practices, including instructional strategies and planning. The following questions and responses addressed the participants' views.

Resources/Support: "What instructional tools, if any, might you need to effectively incorporate the components of DI to support SPED students within your inclusion-based classes?" During the interview, some teachers reported that it would be beneficial to overcome some of the challenges with incorporating the elements of DI by having more planning time, more resources, and a supportive, certified co-teacher. Teacher J expressed the need for more support. She stated, "I would like another teacher in my class to help support and assist me in how to tailor lessons based on the individual needs. At the beginning of the year, we had a SPED teacher push in. Apparently, it stopped without notice." Teacher J elaborated on her experiences with an additional teacher in her class. She stated, "Whenever the SPED teacher would push into my class, she was very helpful. She would assist all my students if needed, not just her SPED students. She would work with groups and read some text aloud."

Teacher I also expressed the need for support by a SPED certified teacher. She stated,

As a SPED teacher, I agree that general education teachers do need the extra support to combat the number of SPED students being mainstreamed. They [general education teachers] could benefit from planning with a SPED teacher, which would make teaching SPED student less stressful. However, the general education teacher has to be willing to step outside of "the box" and adapt to a new way of teaching.

Teacher F also commented on the need for more support within the classroom. He stated, "The resources needed to make my classroom more effective are PD training, an added endorsement in SPED and push in from SPED teachers." Teachers $\mathrm{G}$, Teacher $\mathrm{C}$, and Teacher $\mathrm{H}$ mentioned the need more hands-on materials, manipulatives, tiered/level learning activities, and more prep time. Teacher B, H, and I mentioned the use of technology to assist with differentiating instruction to support SPED students. Teacher B said, "My biggest challenge with differentiating instruction for my students is planning and availability." She was asked to elaborate. She stated, "Due to the lack of funding for ESLO teachers, I travel between two schools, which also puts some constraints on my time and availability to collaborate, plan, and be a resource for teachers." Teacher H expressed her biggest challenge with DI was timing and planning. She stated, "I personally believe the challenge for me is finding the time to plan properly." Teacher C also commented on time by saying, "It has been difficult to cover the content standards effectively in the amount of time given. When you only have 55-60 minute classes, it is hard to balance your time with students and meet the needs of your SPED students."

Implementing DI in Inclusion-Based Classrooms: All the participants spoke on using a plethora of strategies within their classes. However, they also stated that it takes a lot of time to plan and prepare differentiated activities for their classes. Teacher $\mathrm{C}$ also commented on using varied learning strategies to support SPED students. She stated,

I try to include relevant, high-interest lessons, varied homework assignments, tiered lessons where students are assigned a different task but working on the same objective, interactive note booking, and group activities. However, it takes a lot of planning and preparation time to plan out an elaborate lesson to ensure all needs of students are being met.

Teacher E stated, "I use videos, some leveled articles, graphic organizers, infographics, diagrams, think-pair-share, creative writing, and guided notes, but depending on what is being covered, I may not have enough time to differentiate the content using those activities to see if my students as well as special students lack understanding." Teacher J expressed using reading scores to develop instructional strategies. She said, "I used their MAP scores to group students based on their reading levels. I choose different reading articles tailored to their reading level." Teacher $\mathrm{H}$ mentioned that she gives her students choices on how they would like to express their work. She stated, "I use choice menus for a lot of projects and other assessments. I provide students with tiered options from high-level thinking to low level." She 
was asked to explain more about the choice menus. She stated,

I have various. One that I use more frequently is the tick-tac-toe. With this option, the students can pick three choices, but only one can be a lower-level activity. The other two must be slightly higher. The points could range from 10 pts to 50 pts.

Teacher A stated, "I do one-on-one conferencing in small groups. I also use handouts that allow the students to fill in the blanks with a given word bank. I utilize sentence starters to help my students who struggle with writing, which is almost all of them."

Question 11 asked: "What assessments do you use to assess SPED students' level of understanding according to your standards and the effectiveness of DI in your inclusion-based classroom?" All participants said they either read aloud their tests and quizzes to their students, or they have a read aloud feature on their computers that will read the text to them. Teacher D stated, "I shorten quizzes. Instead of giving them four answer choices, I will give three." Teacher E and $\mathrm{H}$ both stated that they use exit tickets, thumbs up/thumbs down, and whole-class discussions. Some of the teachers mentioned using state and district testing, such as MAP testing, benchmark testing, and USA Test Prep to assess students. Teacher $\mathrm{C}$ elaborated on the use of MAP testing by saying, "MAP testing allows me to make charts and graphs based on their math level. It gives me instant feedback." Teacher I mentioned using grading rubrics as form of assessment. Teacher A commented on the use of MAP scores, she stated, "In addition to MAP scores, I use open notes, drawings, and shortened questions."

Question 12: "If you use the components of DI within your inclusive classroom setting, what are some examples of activities you have used to engage your SPED students?" Teacher D stated, "I use projects to show levels of understanding."

Teacher H commented on the use of projects with her ELA students. She said, "One of the activities I have used with my students is called the Escape Room. The Escape Room is set up in stations. The stations are on all ability levels." Teacher G stated that he uses gallery walks. He stated, "Gallery walks are great way to assess student knowledge. I will post questions or images with a caption. The students are given time to walk around and write the answer to the question or their analysis of the image. After the allotted time, we will have a class discussion." Teacher I and Teacher J both expressed using literature circles, grouping, and book choice as activities to differentiate levels of understanding. Teacher E stated, "I use a lot of graphic organizers, interactive labs, lab stations, and color-coding activities with my science students." Teacher $\mathrm{C}$ commented about using foldable. She stated, "I have my students create a foldable on various math operations to help with building understanding."

Using Technology in DI: Teacher H stated, "I used Kahoot, an educational game to help with my diverse learners. I also use videos." Teacher I also commented on the use of technology by stating, "I used a lot of video segments to discuss a particular topic and visual aids, such as pictures, to help teach my students new concepts." Teacher B, H, and I mentioned the use of technology to assist with differentiating instruction to support SPED students. Teacher B said, "I used Quizlet to help build vocabulary with my ESOL students. With this computer application, I can create quizzes, flashcards, and matching games to help build their vocabulary and understanding. It takes a good amount of planning to create the Quizlets to ensure that I am providing them the content of various subjects." Teacher A also mentioned the use of technology to differentiate the instruction in her inclusion-based classrooms, such as digital notebooks. She stated that this notebook is online, and it allows her SPED students a way of taking notes in class without having to write them down. In addition, she mentioned using a "flipped classroom." She further explained, "A flipped classroom is when she records her lesson and uploads it for students to watch. This allows them to stop and play as they see fit." Teacher H, Teacher B, and Teacher I all stated they use collaborative teaching, technology, and guided notes to assist SPED students. Overall, all the participants expressed the need for more resources and materials to incorporate the components of DI effectively within their inclusion-based classrooms.

In summary, the data collected showed a discrepancy in the timing, planning, and lack of knowledge about DI. Individual interviews were conducted and provided data on the use, or lack thereof, of DI within an inclusion-based classroom. The data collected explored the experiences of rural middle school teachers and the challenges they are faced with, or lack thereof, when using DI to support SPED students in an inclusion-based classroom.

The responses of the participants in the interviews provided a deeper understanding of challenges associated with incorporating DI to support a diverse population. Participants revealed that DI, when used, can be beneficial to all students and enhance learning for SPED students. They also expressed the challenges in doing so. Participants felt they lacked the knowledge, time/preparation, resources/materials, and professional development training opportunities to be able to incorporate the elements of DI effectively. Further, most teachers had a basic understanding of DI, but some 
teachers had a better understanding.

\subsection{Observations}

Seven out of the ten participants' observations presented adequate evidence showing the use of DI within their inclusion-based classrooms. All 10 of the participants had their standards and objectives for the lesson posted on the board. Participants A, B, and I read the objectives aloud to the students letting them know what they will know and understand from the lesson being presented. In all the classes observed, the students were engaged during the lesson. Students were raising their hands to participate and answer questions.

Three of the ten participants showed strong evidence of DI with the layout of their classroom creating accessibility to grouping for teacher and student engagement. Participant A, an ELA class, had her desks arranged in groups of four. She also had a semi-circle table where she did a conference with students on their writing. Similarly, Participant D, a science teacher, had his desks arranged in groups of four. Participants B and I also had a semi-circle table that allowed approximately five students to sit at the table with a teacher. At the time of their observations, both teachers were working with students individually, while the other students were working independently on another assignment given by the teacher.

All ten of the participants showed adequate evidence of their use of materials and resources. All the participants had Smartboards within their classrooms, as well as Chromebooks for student use. All the participants used their Smartboards to present their instruction or integrated the use of the Chromebooks. Participant C, D, and E required their students to use interactive notebooks to keep and store all the information that was given by their teacher. It was observed that students cut and paste foldables inside their interactive notebooks, as well as taking notes.

A majority of the participants showed adequate use of various instructional strategies during their inclusion-based classes. Participant A had her students annotating in their notebooks while she read a book aloud to them. She modeled how to annotate while the students followed along in their notebooks. During the modeling, she explained her thinking while making connections to the learning objective. Participant E also used a variety of instructional strategies to deliver her content. She began the class with "Buzz Questions," which students were prompted to answer using their Chromebooks. She showed a small video clip on the content being covered. She also asked a variety of questions about the video throughout her lesson. The questions were purposeful and connected to the lesson's learning objective.

Seven of the ten participants accessed prior knowledge during the class by starting class off with some form of five-minute warm-up. The warm-ups consisted of a writing prompt, multiple-choice questions, or an image to access prior knowledge drawing connections to the standard. Although many of the participants did not show evidence of student choice, Participant A and E provided their students with choice. Participant A gave her students a choice to read for 20 minutes or write at the start of class. Participant $\mathrm{E}$ gave her students a choice to write a summary of their science article on notebook paper, type it using their Chromebooks, or draw a picture to display the contents of the article.

Although the findings from the interview process reflected teachers' acknowledgement of the importance of using DI to support all students, during the observations, there appeared to be a consensus amongst all the participants that there is a lack of time to incorporate DI within their inclusion-based classrooms to help SPED students. The data collected also reflect teachers' willingness to attempt to incorporate DI, but knowledge and understanding of how to effectively implement and utilize the components of DI is not always transferred to the classroom.

\subsection{Review of Documents}

Lesson plans. Of the ten participants, three teachers submitted lesson plans for the review of documents. The intended purpose of the lesson plans was to look for evidence of DI: activities aligned with standards, variety of activities, evidence of small groups/flexible learning, and implementation of ongoing assessments (formal or informal). Teacher $\mathrm{H}$, Teacher F, and Teacher D submitted lessons plans (See Figures 1-3). 


\begin{tabular}{|c|c|c|c|}
\hline Evidence of:DI $\rightarrow a$ & Strong? & Adequate 3 & None $\cdot x$ \\
\hline Lesson planned for diverse students $\alpha$ & 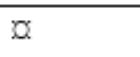 & $\mathrm{X} \alpha$ & $x$ \\
\hline $\begin{array}{l}\text { Implementation of ongoing - } \\
\text { assessmentso. }\end{array}$ & $\alpha$ & $\alpha$ & $\alpha$ \\
\hline $\begin{array}{l}\text { Lesson'support 'standards/content- } \\
\text { and topics }: 0\end{array}$ & $\mathrm{X} x$ & $\alpha$ & $\alpha$ \\
\hline $\begin{array}{l}\text { Use of a variety of - instructional- } \\
\text { strategies and-activities used to- } \\
\text { teach the-lessona. }\end{array}$ & $\mathrm{X} \alpha$ & $\alpha$ & $\alpha$ \\
\hline $\begin{array}{l}\text { Evidence of -small-groups or flexible- } \\
\text { learningo. }\end{array}$ & $\alpha$ & $\mathrm{X} a$ & $\alpha$ \\
\hline $\begin{array}{l}\text { Evidence of projects and problem- } \\
\text { solving activities }\end{array}$ & $\mathrm{X}$ & $\alpha$ & $\alpha$ \\
\hline $\begin{array}{l}\text { Evidence of student choice- } \\
\text { activities: }\end{array}$ & $\alpha$ & $\alpha$ & $\mathrm{X} \alpha$ \\
\hline
\end{tabular}

Figure 1. Teacher H Review of Documents (Lesson Plans)

\begin{tabular}{|c|c|c|c|c|}
\hline Evidence of $\cdot D I \rightarrow a$ & Stro & Ade & None'a & $\alpha$ \\
\hline Lesson planned for diverse students $: 0$ & 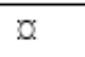 & $\mathrm{X} \alpha$ & $\alpha$ & d \\
\hline $\begin{array}{l}\text { Implementation of ongoing - } \\
\text { assessments }{ }^{\circ} \text {. }\end{array}$ & $\alpha$ & $\mathrm{Xo}$ & $a$ & $\alpha$ \\
\hline $\begin{array}{l}\text { Lesson plans support standards/content - } \\
\text { of topics } \alpha\end{array}$ & $\mathrm{X} x$ & $\alpha$ & $a$ & $\alpha$ \\
\hline $\begin{array}{l}\text { Use-of-a variety-of instructional- } \\
\text { strategies and activities used to teach- } \\
\text { the-lessono. }\end{array}$ & $\mathrm{Xo}$ & $x$ & $a$ & $\alpha$ \\
\hline $\begin{array}{l}\text { Evidence of small-groups or flexible- } \\
\text { learningo }\end{array}$ & $\mathrm{X} \alpha$ & $\alpha$ & $\alpha$ & $\alpha$ \\
\hline $\begin{array}{l}\text { Evidence of projects and problem- } \\
\text { solving activities } 0\end{array}$ & $\alpha$ & $\mathrm{Xo}$ & $x$ & $\alpha$ \\
\hline Evidence of student choice activities 0 & $\alpha$ & $x$ & $\mathrm{X} \alpha$ & $\alpha$ \\
\hline
\end{tabular}

Figure 2. Teacher H Review of Documents (Lesson Plans) 


\begin{tabular}{|c|c|c|c|c|}
\hline Evidence of $\cdot \mathrm{DI} \rightarrow \mathrm{a}$ & Strong $x$ & Adequate? & None'a & a \\
\hline Lesson planned for diverse students $: \alpha$ & $\alpha$ & $\mathrm{X} \alpha$ & $x$ & a \\
\hline Implementation of ongoing assessments & a & $\mathrm{X} \alpha$ & a & a \\
\hline $\begin{array}{l}\text { Lesson plans support-standards and- } \\
\text { topicsó. }\end{array}$ & $\mathrm{X} \alpha$ & $\alpha$ & a & a \\
\hline $\begin{array}{l}\text { Use of a variety of instructional } \\
\text { strategies and activities used to teach the } \\
\text { lessond. }\end{array}$ & $\alpha$ & $\alpha$ & $\mathrm{X} a$ & a \\
\hline $\begin{array}{l}\text { Evidence of 'small-groups 'or flexible- } \\
\text { learningo. }\end{array}$ & $\alpha$ & $\mathrm{X} \alpha$ & a & a \\
\hline $\begin{array}{l}\text { Evidence of projects and problem- } \\
\text { solving activities }\end{array}$ & a & a & $\mathrm{X} a$ & a \\
\hline Evidence of -student choice activities $\alpha$ & a & a & $\mathrm{X}$ & a \\
\hline
\end{tabular}

Figure 3. Teacher F Review of Documents (Lesson Plans)

Participant $\mathrm{H}$ listed her standards and objectives for the lesson being taught. She recorded the vocabulary associated with the lesson. She also listed all the supplies/materials the students will be using throughout the lesson. On her lesson plans, she had a section listing how she planned to differentiate her instruction: using guided notes, ESOL students were given copies of guided records in Spanish and English as well as PowerPoint copies in Spanish translated to English. She had a variety of ongoing assessments: Kahoot answer, illustration activity, and homework.

Participant $\mathrm{F}$ had social studies standards and objectives listed at the top of his lesson plans. He also had a list of vocabulary words that the students will be using during this lesson. He recorded a variety of activities and the implementation of technology to engage his students and appeal to his SPED population, such as video clips, graphic organizers, and collaborative pairs. His ongoing assessments were Web Quests on a famous medieval figure, quizzes, and "war games". However, there was no evidence of student choice.

Participant D submitted his lesson plans for review. He had the standard and objectives listed, and an activity that was aligned with the standard. He recorded the vocabulary that students should know for this standard. For assessments, he listed "teacher observation". However, he listed some ongoing assessments under homework (i.e., lab report, complete chemical formula color sheet). He also had a section titled "differentiated instruction." In this section, there were sub-headings: At-Risk and Accelerated. For at-risk, he listed how he was going to differentiate instruction using visual aids and/or teacher assistants. For accelerated, he listed "work independently" and "visual aids". Although he had what type of lesson he was going to deliver, he did not list how he was going to execute the activities. There was not any indication for student choice presented on the lesson plans. He included what type of lesson he was going to deliver, but he did not list how he was going to execute the activities. There was not an indication for student choice presented on the lesson plan.

Classwork/worksheets Four of the participants submitted documents in this category. The documents included graphic organizers, writing assignments, labeling diagrams, concept maps, and comprehension questions. The purpose of each of the documents submitted was for students to apply their understanding of the concepts being covered or to review the concepts that have been covered in class (see Figure 4-6). 


\begin{tabular}{|c|c|c|c|c|}
\hline Evidence of'DI $\rightarrow$ a & Strong $x$ & Adequater & None'a & $a$ \\
\hline Lesson planned for diverse students $\alpha$ & $\alpha$ & $\mathrm{X} \alpha$ & $\alpha$ & a \\
\hline Implementation of ongoing assessments $\mathrm{C}$ & $\alpha$ & $\mathrm{X} \alpha$ & $\alpha$ & $\alpha$ \\
\hline $\begin{array}{l}\text { Lesson plans support-standards and- } \\
\text { topicsa. }\end{array}$ & $\mathrm{X} \alpha$ & $\alpha$ & $\alpha$ & $\alpha$ \\
\hline $\begin{array}{l}\text { Use of a variety of instructional- } \\
\text { strategies and activities used to teach the- } \\
\text { lessond. }\end{array}$ & a & $a$ & $\mathrm{X} \alpha$ & a \\
\hline $\begin{array}{l}\text { Evidence-of small-groups or flexible- } \\
\text { learningd. }\end{array}$ & $\alpha$ & $\mathrm{X} \alpha$ & $\alpha$ & a \\
\hline $\begin{array}{l}\text { Evidence of projects and problem- } \\
\text { solving activities }\end{array}$ & $\alpha$ & $\alpha$ & $\mathrm{Xo}$ & $\alpha$ \\
\hline Evidence of student choice activities $\alpha$ & $\alpha$ & $x$ & $\mathrm{X} \alpha$ & $a$ \\
\hline
\end{tabular}

Figure 4. Teacher B Review of Documents (Classwork/Worksheet)

\begin{tabular}{|c|c|c|c|c|}
\hline Evidence of $\cdot D I \rightarrow a$ & Strong $x$ & Adequate's & None'a & $x$ \\
\hline Lesson planned for diverse students $: \alpha$ & $\alpha$ & $\mathrm{X} \alpha$ & $x$ & $\alpha$ \\
\hline Implementation of ongoing assessments & $\alpha$ & $\mathrm{X} \alpha$ & $\alpha$ & $x$ \\
\hline $\begin{array}{l}\text { Lesson plans support standards and- } \\
\text { topicsó. }\end{array}$ & $\mathrm{X} \alpha$ & $\alpha$ & $\alpha$ & $\alpha$ \\
\hline $\begin{array}{l}\text { Use of a variety of instructional- } \\
\text { strategies and activities used to teach the- } \\
\text { lessono. }\end{array}$ & $a$ & $\mathrm{X} \alpha$ & $a$ & $a$ \\
\hline $\begin{array}{l}\text { Evidence of small-groups or flexible- } \\
\text { learningd }\end{array}$ & $\alpha$ & $\mathrm{X} \alpha$ & $\alpha$ & $\alpha$ \\
\hline $\begin{array}{l}\text { Evidence of projects and problem- } \\
\text { solving activities } \bar{\alpha}\end{array}$ & $\alpha$ & $a$ & $\mathrm{X}$ & $a$ \\
\hline Evidence of student choice activities $\alpha$ & $\alpha$ & $x$ & $\mathrm{X} x$ & $\alpha$ \\
\hline
\end{tabular}

Figure 5. Teacher G Review of Documents (Classwork/Worksheet) 


\begin{tabular}{|c|c|c|c|c|}
\hline Evidence'of'DI $\rightarrow a$ & Stro & Ade & None $\cdot a$ & 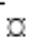 \\
\hline Lesson planned for diverse students $: \alpha$ & $\not \alpha$ & $\mathrm{X} \alpha$ & $\alpha$ & a \\
\hline Implementation of ongoing assessments $\alpha$. & $\alpha$ & $\mathrm{X} \alpha$ & $\alpha$ & $x$ \\
\hline $\begin{array}{l}\text { Lesson plans 'support'standards and } \\
\text { topicsó. }\end{array}$ & $\mathrm{X}$ & $\alpha$ & $\alpha$ & a \\
\hline $\begin{array}{l}\text { Use of a variety of -instructional- } \\
\text { strategies and activities used to teach the- } \\
\text { lessond. }\end{array}$ & $\not a$ & $\mathrm{X} \alpha$ & $\alpha$ & 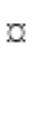 \\
\hline $\begin{array}{l}\text { Evidence-of 'small'groups 'or-flexible- } \\
\text { learningd. }\end{array}$ & $\alpha$ & $\alpha$ & $\mathrm{X} \alpha$ & a \\
\hline $\begin{array}{l}\text { Evidence of projects and problem- } \\
\text { solving activities } 0\end{array}$ & $\alpha$ & $\mathrm{X} \alpha$ & $\alpha$ & $\alpha$ \\
\hline Evidence-of student choice activities $\alpha$ & $\alpha$ & $\mathrm{X} \alpha$ & $a$ & $\alpha$ \\
\hline
\end{tabular}

Figure 6. Teacher G Review of Documents (Classwork/Worksheet)

Participant B, ESOL teacher, submitted a worksheet on prefixes and making connections to the learning objectives. Prefixes was defined at the top of the worksheet. It provided a prefix and meaning. The students had to circle the prefixes in each sentence. On the back of the worksheet, the students were required to pick three of the prefixes and create a new word which assessed the student's level of understanding. The document did not display evidence of projects/problem-solving or small groups/flexibility. The students were not given another option to show their level of understanding on this handout.

Participant G, a social studies teacher, submitted two graphic organizers on the content that was covered during his observation. The worksheet was connected to the learning objective. One the worksheets had some answers already filled it (lower level students), and the other had no answers filled in. The students had to use their notes complete the worksheet. The worksheet did not show evidence of student choice or projects/problem-solving.

Participant E, a science teacher, submitted a worksheet that required the students to label, color, draw, and answer questions about what they were learning, providing the students with a variety of ways to display their understanding. The worksheet required the students to interpret and analyze information showing adequate evidence of problem-solving. However, the worksheet did not show evidence of flexible or small grouping.

Projects. One of the participants submitted project descriptions. The documents included were individual projects and group projects with writing or presentation components. The students had the option to turn in a written document or present their work via Google Slides. All documents aligned with the state standard and objectives (see Figure 7). 


\begin{tabular}{|c|c|c|c|c|}
\hline Evidence of $\cdot D I \quad \rightarrow \quad a$ & Stro & Ade & None $\cdot a$ & a \\
\hline Lesson planned for diverse students $: \alpha$ & $a$ & $\mathrm{X} \alpha$ & $\alpha$ & a \\
\hline Implementation of ongoing assessments $\mathrm{C}$ & $\alpha$ & $\mathrm{X} \alpha$ & $\alpha$ & a \\
\hline $\begin{array}{l}\text { Lesson plans support standards and } \\
\text { topicso: }\end{array}$ & $\mathrm{X} \alpha$ & $\alpha$ & $\alpha$ & a \\
\hline $\begin{array}{l}\text { Use of a variety of instructional- } \\
\text { strategies and activities used to teach the } \\
\text { lessona. }\end{array}$ & $\alpha$ & $\mathrm{X}$ & $\alpha$ & ; \\
\hline $\begin{array}{l}\text { Evidence of -small-groups 'or flexible- } \\
\text { learninga. }\end{array}$ & a & a & $\mathrm{X} \alpha$ & a \\
\hline $\begin{array}{l}\text { Evidence of projects and problem- } \\
\text { solving activities } \alpha\end{array}$ & $\mathrm{X} \propto$ & $\alpha$ & $\alpha$ & a \\
\hline Evidence of student choice activities $\alpha$ & $\mathrm{X} a$ & a & a & 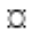 \\
\hline
\end{tabular}

Figure 7. Teacher Review of Documents (Assessment)

Participant A, an ELA teacher, submitted a project description about mental disorders. The students were given a choice as to what disorder they wanted to research. They were also given a choice on how they wanted to present their findings (i.e. foldable, PowerPoint, or poser board). A grading rubric was also attached to the project description. The assessment had measurement criteria and measured student performance in more than one way. She was assessing their writing, content, and creativity. The project was aligned with the standard and learning objectives being taught. The project was individualized; therefore, no evidence was presented showing small groups or problem-solving activities.

Assessments. Three of the participants submitted an assessment, either a test or quiz. The purpose of each assessment was to determine the students' level of knowledge and understanding of the topic being covered (see Figure 8-10).

\begin{tabular}{|c|c|c|c|}
\hline Evidence $\cdot$ of'DI $\rightarrow a$ & Strong $x$ & Adequater & None $\cdot d$ \\
\hline Lesson planned for diverse students $: \alpha$ & $\alpha$ & $\mathrm{X} a$ & $\alpha$ \\
\hline Implementation of ongoing assessments $\alpha$ & $\alpha$ & $\mathrm{X} a$ & $a$ \\
\hline $\begin{array}{l}\text { Lesson plans support standards and } \\
\text { topics } 0 \text {. }\end{array}$ & $\mathrm{X} \alpha$ & a & $\alpha$ \\
\hline $\begin{array}{l}\text { Use of a variety of instructional } \\
\text { strategies and activities used to teach the- } \\
\text { lessono. }\end{array}$ & $\alpha$ & $\mathrm{X} \alpha$ & $x$ \\
\hline $\begin{array}{l}\text { Evidence of small-groups or flexible- } \\
\text { learningo. }\end{array}$ & $\alpha$ & $\mathrm{X} \alpha$ & $\alpha$ \\
\hline $\begin{array}{l}\text { Evidence of projects and problem- } \\
\text { solving activities } \alpha\end{array}$ & $\alpha$ & $\mathrm{X} \alpha$ & $x$ \\
\hline Evidence of student choice activities $\alpha$ & $\alpha$ & $\alpha$ & $\mathrm{X} \alpha$ \\
\hline
\end{tabular}

Figure 8. Review of Documents (Assessment) 


\begin{tabular}{|c|c|c|c|c|}
\hline Evidence of-DI $\rightarrow a$ & Strong $x$ & Adequate? & None'a & $=$ \\
\hline Lesson planned for diverse students $:$ & $x$ & $\alpha$ & $\mathrm{X} \alpha$ & : \\
\hline Implementation of ongoing assessments & $x$ & $\mathrm{X} \alpha$ & $\alpha$ & : \\
\hline $\begin{array}{l}\text { Lesson plans support-standards and - } \\
\text { topicsö. }\end{array}$ & $\mathrm{X} \alpha$ & a & $\alpha$ & $\mathrm{c}$ \\
\hline $\begin{array}{l}\text { Use of a variety of instructional } \\
\text { strategies and activities used to teach the- } \\
\text { lesson } 0 \text {. }\end{array}$ & $a$ & $\alpha$ & $\mathrm{X} \alpha$ & : \\
\hline $\begin{array}{l}\text { Evidence of -small-groups 'or flexible- } \\
\text { learningo. }\end{array}$ & $a$ & $\mathrm{X} \alpha$ & $a$ & a \\
\hline $\begin{array}{l}\text { Evidence of projects and problem- } \\
\text { solving activities } \alpha\end{array}$ & $x$ & $\mathrm{X} \alpha$ & $\alpha$ & a \\
\hline Evidence of student choice activities & $x$ & $\alpha$ & $\mathrm{X} \alpha$ & a \\
\hline
\end{tabular}

Figure 9. Teacher C Review of Document (Assessment)

\begin{tabular}{|c|c|c|c|c|}
\hline Evidence of $\cdot D I \quad \rightarrow \quad a$ & Strong $x$ & Adequater & None $\cdot a$ & $x$ \\
\hline Lesson planned for diverse students $: 0$ & a & $\mathrm{X} \alpha$ & $\alpha$ & a \\
\hline Implementation of -ongoing assessments $\mathrm{C}$ & $a$ & $\mathrm{X} \alpha$ & $\alpha$ & a \\
\hline $\begin{array}{l}\text { Lesson plans support standards and- } \\
\text { topicsí. }\end{array}$ & $\mathrm{X} \alpha$ & $x$ & $\alpha$ & $\alpha$ \\
\hline $\begin{array}{l}\text { Use of - variety of instructional- } \\
\text { strategies and activities used to teach the- } \\
\text { lessond }\end{array}$ & $x$ & $x$ & $\mathrm{X} x$ & $\alpha$ \\
\hline $\begin{array}{l}\text { Evidence of 'small-groups or flexible- } \\
\text { learningo. }\end{array}$ & $x$ & $\mathrm{X} a$ & $\alpha$ & $\alpha$ \\
\hline $\begin{array}{l}\text { Evidence of projects and problem- } \\
\text { solving activities }\end{array}$ & $x$ & $a$ & $\mathrm{X} x$ & a \\
\hline Evidence of student choice activities 0 & a & $x$ & $\mathrm{X}$ & a \\
\hline
\end{tabular}

Figure 10. Teacher J Review of Documents (Assessment)

Participant I submitted a 25-question assessment. She stated, "I gave this assessment via Google Forms." She proceeded to say, "Many of my students have oral accommodations, and the Chromebooks have a read-aloud application that students can access. The computer will read the questions and answer choices out to the students once the students are finished. Upon the submission of their quiz, the students will receive their score." The assessment submitted was a multiple-choice reading quiz. However, the questions were short and concise, with fewer answer choices. The assessment was aligned with state content standards.

Participant C, a math teacher, also submitted a Google Form for review of documents. It was a 20-question math test using rational and irrational numbers. She stated, "I provide each student with a hard copy of the test allowing the students to show how they solved the problems and circle their answer. Once they have completed their test, each student is required to submit their answers using the Google Form." The assessment provided measured student performance in the form of multiple choice. The assessment was aligned with state standards.

Participant J, an ELA teacher, submitted a 20-question reading comprehension assessment. The students had to read a passage and answer some questions related to the passage. The assessment had more than one way to measure student performance: multiple-choice, short answer, and essay. She presented evidence of having small groups with her 
assessment. When she submitted her assessment, she informed the researcher that she often forms a small group within her class to read the test aloud for those students who have oral accommodations. The assessment was aligned with state content standards. There was no evidence of student choice. The assessment was aligned with state content standards.

The review of documents showed teachers incorporating some components of DI within their inclusion-based classrooms. The data collected also reflect teachers' willingness to attempt to incorporate DI, but knowledge and understanding of how to effectively implement and utilize the components of DI is not always transferred to instructional practices.

\section{Discussion}

Using the information from this research study, district administrators can address middle school teachers' challenges incorporating DI components, which may lead to positive change. Improving middle school teachers' knowledge and incorporation of DI could lead to more effective instruction that uses the components of DI to support SPED students and increase overall student achievement. Tomlinson (2014) recommended research-based instructional strategies that accommodate students with varying instructional needs. When instruction is individualized to fit students' needs, student achievement is enhanced and there are positive outcomes. The positive outcomes include articulation of the curriculum, identification of learning differences through assessments, and collaboration (Taylor, 2015).

Implications for the research are a change in instructional practices and ongoing professional development that address incorporating DI in middle school inclusion classrooms for all content areas. This study could be implemented at other middle schools in the district to extend the collaborative reach of the professional development program. The information gathered throughout this study could be shared with continuing education programs or district teacher evaluation programs to create more effective teacher preparation programs. Further, an extension of the research to include more middle schools and high schools within the district would be beneficial.

\section{References}

Avery, R. A. (2017). Teacher willingness on implementing differentiated instruction (DI) in the elementary classroom: A multiple case study (Doctoral dissertation). ProQuest Dissertations \& Theses Global. Accession number (1964252438)

Bicehouse, V., \& Faieta, J. (2016). IDEA at age forty: Weathering common core standards and data driven decision making. Contemporary Issues in Education Research (CIER), 10(1), 33. https://doi.org/10.19030/cier.v10i1.9878

Darrow, A. (2016). Every Student Succeeds Act (ESSA). General Music Today, 30(1), 41-44. https://doi.org/10.1177/1048371316658327

Dixon, F. A., Yssel, N., McConnell, J. M., \& Hardin, T. (2014). Differentiated instruction, professional development, and teacher efficacy. Journal for the Education of the Gifted, 37(2), 111-127. https://doi.org/10.1177/0162353214529042

Every Student Succeeds Act (ESSA). (2015.). Retrieved from https://www.ed.gov/ESSA

Florian, L., \& Beaton, M. (2017). Inclusive pedagogy in action: getting it right for every child. International Journal of Inclusive Education, 22(8), 870-884. https://doi.org/10.1080/13603116.2017.1412513

Forrester, S. O. (2016). Relationships among middle school teachers' perceptions regarding inclusion of students with disabilities in general education classrooms (Order No. 10010919). Available from ProQuest Dissertations \& Theses Global. (1765463928). Retrieved from https://ezp.waldenulibrary.org/login?qurl=https\%3A\%2F\%2Fsearch.proquest.com\%2Fdocview\%2F176546392 $8 \% 3 \mathrm{Facc}$

Lochner, B., Conrad, R., \& Graham, E. (2015). Secondary teachers concern in adopting learning management systems: A U.S. perspective. TechTrends, 59(5), 62-70. https://doi.org/10.1007/s11528-015-0892-4

National Center for Education Statistics (NCES). (2017). Home Page, part of the U.S. Department of Education. (n.d.). Retrieved from http://nces.ed.gov/

Nicolae, M. (2014). Teachers' beliefs as the differentiated instruction starting point: Research basis. Social and Behavioral Sciences, 128, 426-431. https://doi.org/10.1016/j.sbspro.2014.03.182

No Child Left Behind Act of 2001, Pub. L. 107-110, 115, 20 U.S.C. § 6319 (2002) 
Prince, B. L. (2011). Teacher perceptions of differentiated instruction (Order No. 3460876). Available from Dissertations \& Theses at Walden University; ProQuest Central; ProQuest Dissertations \& Theses Global. (879043001). Retrieved

from https:/ezp.waldenulibrary.org/login?qurl=https $\% 3 \mathrm{~A} \% 2 \mathrm{~F} \% 2 \mathrm{Fsearch}$.proquest.com\%2Fdocview $\% 2 \mathrm{~F} 879043001$ $\% 3$ Faccou

Royster, O., Reglin, G., \& Losike-Sedimo, N. (2014). Inclusion professional development model and regular middle school educators. Journal of at Risk Issues, 18(1), 1-10. Retrieved from www.waldenu.edu/ERIC

SC Department of Education. (2015). South Carolina department of education. Retrieved from www.ed.sc.gov

Steinmeyer, J. (2011). Implementation of differentiated instruction in inclusion classroom effectiveness (Order No. 3482514). Available from Dissertations \& Theses at Walden University; ProQuest Central; ProQuest Dissertations \& Theses Global. Retrieved from https://ezp.waldenulibrary.org/login

Taylor, R. W., \& Ringlaben, R. P. (2012, July 19). Impacting pre-service teachers' attitude toward inclusion. Higher Education Studies, 2(3), 1-8. https://doi.org/10.5539/hes.v2n3p16

Tomlinson, C. (2014). The differentiated classroom: Responding to the needs of all learners (2nd ed.). Alexandria, VA: Association for Supervision and Curriculum Development.

Tomlinson, C., \& Imbeau, M. (2011). Leading and managing a differentiated classroom. Alexandria, VA: Association for Supervision and Curriculum Development.

U.S. Department of Education. (n.d.). Retrieved from https://www.ed.gov/

Wiles, J., \& Bondi, J. (2015). Curriculum development (9th ed.). Boston, MA: Pearson. 